\title{
Effect of feeding extruded flaxseed with different forage:concentrate ratios on the performance of dairy cows
}

\author{
C. Neveu, ${ }^{*}$ B. Baurhoo, $\dagger^{1}$ and A. Mustafa*1 \\ *Department of Animal Science, McGill University, Ste-Anne-De-Bellevue, Quebec, H9X 3V9 Canada \\ †Bélisle Solution and Nutrition Inc., Saint-Mathias sur Richelieu, Quebec, J3L 6A7 Canada
}

\begin{abstract}
Twenty Holstein cows were used in a Latin square design experiment with a $2 \times 2$ factorial arrangement to determine the effects of extruded flaxseed (EF) supplementation with 2 different forage to concentrate ratios on the performance of dairy cows. Extruded flaxseed diets contained 9\% (dry matter basis) EF product which consisted of $75 \% \mathrm{EF}$ and $25 \%$ ground alfalfa meal. Four lactating Holsteins cows fitted with rumen fistulae were used to determine the effects of dietary treatments on ruminal fermentation. Intakes of dry matter and crude protein were not influenced by dietary treatments. However, neutral detergent fiber intake was greater for the high-forage $(8.4 \mathrm{~kg} / \mathrm{d})$ than the low-forage $(7.8 \mathrm{~kg} / \mathrm{d}$ ) diet. Milk yield (average $40.2 \mathrm{~kg} / \mathrm{d}$ ) was similar for all dietary treatments. However, cows fed the high-forage diets produced milk with higher fat (3.76 vs. 2.97\%) and total solids (12.58 vs. $11.95 \%$ ) concentrations, but lower protein (3.19 vs. $3.33 \%$ ) and lactose (4.66 vs. $4.72 \%$ ) contents. Ruminal $\mathrm{pH}$ and total volatile fatty acid concentration were not affected by dietary treatments. However, feeding high forage relative to low forage diets increased molar proportion of acetate but decreased that of propionate. Ruminal $\mathrm{NH}_{3}-\mathrm{N}$ was reduced by feeding high forage relative to low forage diets. Milk fatty acid composition was altered by both forage level and EF supplementation. Feeding diets containing EF or low forage reduced the concentrations of saturated fatty acids and increased those of mono-unsaturated fatty acids. Concentrations of poly-unsaturated fatty acids were increased by feeding EF or low-forage diets. Extruded flaxseed supplementation increased milk fat $\alpha$-linolenic acid content by $100 \%$ and conjugated linoleic acid by $54 \%$. It was concluded that differences in animal performance and ruminal fermentation observed in this study were mostly due to differences in forage to concentrate
\end{abstract}

\footnotetext{
Received September 23, 2012.

Accepted February 19, 2013.

${ }^{1}$ Corresponding authors: arif.mustafa@mcgill.ca and bbaurhoo@ belisle.net.
}

ratio. However, EF supplementation caused most of the differences observed in milk fatty acid composition.

Key words: dairy cow, extrusion, fatty acid, flaxseed

\section{INTRODUCTION}

Flaxseed is a rich source of linolenic acid, averaging $18 \%$ of the total seed weight and constituting $53 \%$ of the total FA (Gonthier et al., 2004). Feeding whole, rolled, or extruded flaxseed (EF) to dairy cows increased concentrations of milk unsaturated FA and decreased the concentrations of SFA, particularly C16:0 (Mustafa et al., 2003; Akraim et al., 2007). However, feeding flaxseed produced relatively small changes in the concentrations of $\mathrm{C} 18: 2$ and C18:3 in milk due to the extensive biohydrogenation of these FA in the rumen. Altering the physical structure of flaxseed (e.g., through heat treatment) may help to protect dietary FA of oilseeds from ruminal biohydrogenation (Chouinard et al., 1997; Sterk et al., 2011). Application of heat treatments, such as extrusion, to oilseeds can denature the protein matrix surrounding the fat droplet and therefore protects fat from ruminal biohydrogenation (Kennelly, 1996). During the extrusion process of oilseeds, the rapid release of intracellular oil may lead to considerable oil losses. Therefore, addition of a binder may help to reduce oil losses during extrusion of oilseeds (Akraim et al., 2007).

A major disadvantage of feeding vegetable oils and oilseeds to dairy cows is the significant reduction in milk fat concentration and yield, mainly due to the formation of several trans and conjugated FA isomers that have adverse effects on de novo FA synthesis (Loor et al., 2005; Chilliard et al., 2007; Glasser et al., 2008). Several dietary factors may affect the extent of FA metabolism in the rumen by altering rumen $\mathrm{pH}$ and the microbial population; these include type and concentration of supplementary fat, forage to concentrate ratio, forage type, and composition of basal diet. Previous studies have shown that the effect of supplementary flaxseed oil on milk FA composition is influenced by the forage to concentrate ratio and forage type (Shingfield et al., 2010; Sterk et al., 2011). To our knowledge, the 
effects of EF addition to diets formulated with different forage to concentrate ratios on the performance and milk FA profile of dairy cows has not yet been reported. The objectives of this study were to determine the effects of supplementation of an EF product (OmegaPlus, Belisle Solution Nutrition Inc., Saint Mathias, Canada) and the manipulation of the forage to concentrate ratio on the performance and milk FA composition of lactating dairy cows.

\section{MATERIALS AND METHODS}

\section{Animals and Experimental Design}

Experimental procedures were approved by the Animal Care Committee of the Faculty of Agricultural and Environmental Sciences of McGill University. Twenty lactating Holsteins cows $(664 \pm 60.8 \mathrm{~kg}$ of BW; $98 \pm$ 29.2 DIM) with different parities were used in a replicated $(\mathrm{n}=5) 4 \times 4$ Latin square experiment with 21 -d periods (14 $\mathrm{d}$ of adaptation and $7 \mathrm{~d}$ of data collection). Cows were housed in tiestalls and had free access to water. Cows were milked twice daily at 0530 and $1700 \mathrm{~h}$.

\section{Dietary Treatments and Sample Collection}

Four diets were formulated to meet nutrient requirements of lactating dairy cows in early lactation (NRC, 2001; Table 1). Dietary treatments were a high-forage $(60 \% \mathrm{DM})$ diet with no $\mathrm{EF}$, a high-forage diet with $\mathrm{EF}$, a low-forage $(40 \% \mathrm{DM})$ diet with no $\mathrm{EF}$, and a low-forage diet with EF. The EF product (OmegaPlus, Belisle Solution Nutrition Inc.) consisted of $75 \%$ flaxseed and $25 \%$ ground alfalfa meal (Table 2). Extrusion was carried out using an Insta-Pro 2000RC extruder (model 2000RC, Insta-Pro International, Des Moines, IA) outfitted with an 8100RC volumetric feeder. Extrusion temperature was maintained around $122^{\circ} \mathrm{C}$.

Diets were fed as a TMR once daily for ad libitum intake. Feed offered and weigh backs of each cow were measured daily during data collection periods (d 15-21 of each period) to determine daily feed intake. Diets were sampled daily during the data collection periods (d 15-21 of each period) and were pooled by period. The pooled samples were oven-dried at $60^{\circ} \mathrm{C}$ for 48 $\mathrm{h}$ and ground through a 1-mm screen using a Wiley mill (Arthur H. Thomas, Philadelphia, PA). Dried and ground samples were then stored at room temperature for later analysis. Fecal samples (200 g) were collected from each cow 4 times daily over a 12 -h period on $\mathrm{d}$ 15 to 17 of each period and dried at $60^{\circ} \mathrm{C}$ in a forcedair oven. Samples were composited by cow, ground and stored for later analysis. Indigestible ADF (IADF) was used as an internal marker to estimate total fecal output
(Huhtanen et al., 1994). Approximately $5 \mathrm{~g}$ of $1-\mathrm{mm}$ ground fecal samples and feed samples were weighed (in duplicate) into nylon bags $(20 \times 10 \mathrm{~cm}, 50 \mu \mathrm{m}$ pore size, Ankom Technology Corporation, Macedon, NY) and incubated in the rumen of a fistulated cow for 12 d. Following incubation, the nylon bags were removed and washed under cold tap water until the wash water was clear from residues. The bags were then oven-dried at $60^{\circ} \mathrm{C}$ for $48 \mathrm{~h}$. The residues were analyzed for ADF and total fecal output was calculated by determining the intake of IADF and dividing IADF intake by IADF concentration in the feces (Kelzer et al., 2009).

Milk samples were collected on d 16 and 18 of each data collection period from morning and evening milkings, combined according to volume, and analyzed for fat, protein, lactose, and MUN using an infrared analyzer (Valacta, Sainte-Anne-de-Bellevue, Canada) according to AOAC (1990, method no. 972.16). Milk samples were also analyzed for TS using standard procedures (AOAC, 1990). Portions of composited samples were frozen for later analysis of FA.

\section{Ruminal Fermentation}

Four multiparous lactating cows $(119 \pm 76.7$ DIM $)$ fitted with rumen fistula were used to determine the effects of dietary treatments on ruminal fermentation. Experimental periods consisted of $14 \mathrm{~d}$ of diet adaptation and $7 \mathrm{~d}$ of data collection. Cows were housed in tiestalls and had continuous access to water. Dietary treatments were the same as in the production study. Samples of rumen fluid were collected from different parts of the rumen with a syringe screwed to a stainless steel tube with a fine metal mesh (RT rumen Fluid Collection Tube, Bar Diamond Inc., Parma, ID) on d 18 and 21 of each period. On d 18, rumen fluid was collected before feeding $(0 \mathrm{~h})$ and at $2,4,6,8,10$, $12 \mathrm{~h}$ post feeding. On d 21, rumen fluid was collected at $1,3,5,7,9,11 \mathrm{~h}$ postfeeding. Ruminal $\mathrm{pH}$ was determined immediately using an Accumet $\mathrm{pH}$ meter (Fisher Scientific, Montreal, Canada). Immediately after $\mathrm{pH}$ determination, $50 \mathrm{~mL}$ of ruminal fluid was preserved by adding $5 \mathrm{~mL}$ of $25 \%$ of metaphosphoric acid for VFA analysis, and $50 \mathrm{~mL}$ of ruminal fluid was also preserved by adding $5 \mathrm{~mL}$ of $0.1 \mathrm{~N} \mathrm{HCl}$ for $\mathrm{NH}_{3}-\mathrm{N}$ analysis. Samples were immediately frozen $\left(-20^{\circ} \mathrm{C}\right)$ for later analysis.

\section{Chemical Analysis}

Dry matter and ash contents of diets and fecal samples were determined using standard procedures (AOAC, 1990). Neutral (Van Soest et al., 1991) and acid (AOAC, 1990) detergent fiber for feed and fecal 
Table 1. Ingredients and chemical composition of dietary treatments

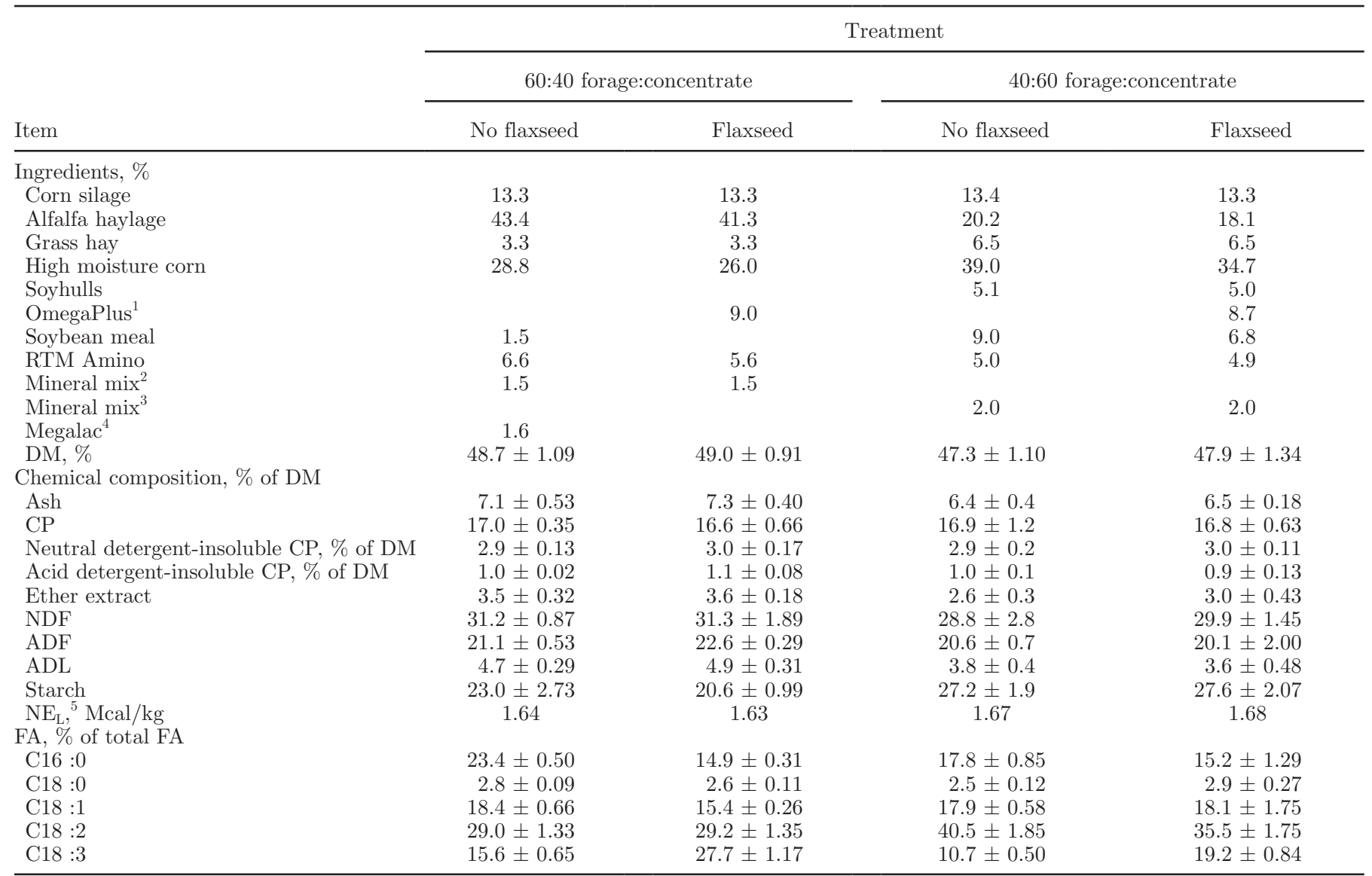

${ }^{1}$ Manufactured by Belisle Solution Nutrition Inc., Saint Mathias, Canada. ${ }^{2}$ Contained $40.65 \%$ dicalcium phosphate, $18.2 \%$ sodium chloride, $13.63 \%$ calcium carbonate, $7.67 \% \mathrm{Mg}, 4.9 \% \mathrm{~K}, 4.52 \% \mathrm{Ca}, 3.4 \% \mathrm{Na}, 0.85 \% \mathrm{Zn}, 0.72 \% \mathrm{Mn}, 0.45 \% \mathrm{Cu}, 0.02 \% \mathrm{Co}, 0.01 \% \mathrm{I}, 0.01 \%$ selenium yeast, $1.52 \%$ mineral oil, $3.11 \%$ canola meal, $1,350 \mathrm{kIU}$ of vitamin $\mathrm{E} / \mathrm{kg}, 400,000 \mathrm{IU}$ of vitamin A/ $\mathrm{kg}$, and $150,000 \mathrm{IU}$ of vitamin D/kg. ${ }^{3} \mathrm{Contained}$ $28.01 \%$ dicalcium phosphate, $16.86 \%$ sodium chloride, $33.98 \%$ calcium carbonate, $5.97 \% \mathrm{Mg}, 5.10 \% \mathrm{~K}, 1.74 \% \mathrm{Ca}, 2.28 \% \mathrm{Na}, 0.71 \% \mathrm{Zn}, 0.60 \%$ $\mathrm{Mn}, 0.38 \% \mathrm{Cu}, 0.02 \% \mathrm{Co}, 0.01 \% \mathrm{I}, 0.01 \%$ selenium yeast, $1.52 \%$ mineral oil, $2.53 \%$ canola meal, $1,150 \mathrm{kIU}$ of vitamin E $/ \mathrm{kg}, 400,000 \mathrm{IU}$ of vitamin $\mathrm{A} / \mathrm{kg}$, and 100, $000 \mathrm{IU}$ of vitamin D/ $\mathrm{kg} .{ }^{4}$ Church and Dwight Inc., Princeton, NJ.

${ }^{5}$ Calculated using the equation of Weiss et al. (1992).

samples were analyzed using an Ankom fiber Analyzer (Ankom Technology). The analysis for NDF was performed without the inclusion of sodium sulfite and with the inclusion of heat-stable $\alpha$-amylase. Acid detergent lignin analysis of feed samples was conducted following AOAC (1990) procedures. Crude protein $(\mathrm{N} \times 6.25)$ was analyzed for both feed and fecal samples using a Leco Nitrogen Analyzer (FP-428 Nitrogen Determinator, Leco Corp., St. Joseph, MI). Neutral and acid detergent insoluble protein of the diets were determined by analyzing NDF and ADF residues, respectively, for total N.

Frozen milk samples were thawed and fat was extracted by centrifugation at $15,000 \times g$ for $25 \mathrm{~min}$ and $0.5 \mathrm{~g}$ of fat was used for FA methyl ester synthesis (O'Fallon et al., 2007). OmegaPlus was analyzed using the same procedure. The internal standard used was tridecanoic acid (C13:0; Nu-Chek Prep Inc., Elysian, $\mathrm{MN})$. Fatty acid composition of the methyl esters was
Table 2. Chemical composition of extruded flaxseed product (OmegaPlus, Belisle Solution Nutrition Inc., Saint Mathias, Canada)

\begin{tabular}{lc}
\hline Item & $\% \mathrm{DM}$ \\
\hline Ash & 6.0 \\
CP & 28.9 \\
NDF & 33.3 \\
ADF & 24.8 \\
Total FA & 15.5 \\
FA & \\
C14:0 & 0.01 \\
C16:0 & 1.06 \\
C16:1 $18: 0$ & 0.01 \\
C18:1n-9c $18: 2 n-6 c$ & 0.48 \\
C18:3n-3 & 2.62 \\
C20:0 & 2.62 \\
C20:5n-3 $22: 0$ & 8.60 \\
C2:0 & 0.02 \\
\end{tabular}


determined by capillary gas chromatography (Varian model 3900 equipped with flame ionization detector at $260^{\circ} \mathrm{C}$ and model 1177 auto injector) fitted with a fused silica capillary column $(\mathrm{CP} 7489,100 \mathrm{~m} \times 0.25 \mathrm{~mm}$; Varian, CA). The carrier gas was $\mathrm{H}_{2}$, and the flow rate was $0.8 \mathrm{~mL} / \mathrm{min}$. Injector and detector temperatures were $260^{\circ} \mathrm{C}$, and the split ratio was $50: 1$. Column temperature was set at $70^{\circ} \mathrm{C}$ for $4 \mathrm{~min}$, and then increased to $130^{\circ} \mathrm{C}$ at a rate of $12.0^{\circ} \mathrm{C} / \mathrm{min}$ and maintained for 3 min. It was then increased to $175^{\circ} \mathrm{C}$ at a rate of $4^{\circ} \mathrm{C} /$ min and was maintained for $27 \mathrm{~min}$. Finally the temperature was increased to $214^{\circ} \mathrm{C}$ at a rate of $4^{\circ} \mathrm{C} / \mathrm{min}$ and maintained for $11 \mathrm{~min}$, then increased to $225^{\circ} \mathrm{C}$ at a rate of $4^{\circ} \mathrm{C} / \mathrm{min}$ and held for $5.5 \mathrm{~min}$; therefore, total run time was $79.25 \mathrm{~min}$. Fatty acids were identified by comparing their retentions times with FA methyl standards (NuChek Prep Inc.).

Samples of ruminal fluid preserved for VFA analysis were centrifuged for $10 \mathrm{~min}$ at $10,000 \times g$ and analyzed for acetic, propionic, and butyric acid using HPLC (Andersson and Hedlund, 1983). The HPLC system included a Milton Roy 711 pump (Milton Roy, Sunderland, UK), a Valco CV-6-UHP injection valve, and an R 401 differential refractometer (Waters, Milford, MA). Separation of VFA was carried out using an Aminex HPX-87H column $(300 \times 7.8 \mathrm{~mm}$; Bio-Rad, Hercules, CA) with a mobile phase of $0.013 M$ of $\mathrm{H}_{2} \mathrm{SO}_{4}$, and a flow rate of $0.6 \mathrm{~mL} / \mathrm{min}$. Detection was made at 210 nm. Ruminal $\mathrm{NH}_{3}-\mathrm{N}$ was determined by colorimetry with a multichannel Lachat Autoanalyzer (Lachat Instruments, Milwaukee, WI).

\section{Statistical Analysis}

Data of the production study and total-tract nutrient utilization were analyzed using the MIXED procedure of SAS (SAS Institute, 1989) as a $4 \times 4$ Latin square design with a $2 \times 2$ factorial arrangement with the following model:

$$
\mathrm{Y}_{i j k}=\mu+\mathrm{E}_{i}+\mathrm{F}_{l}+\mathrm{E}_{i} \times \mathrm{F}_{l}+\mathrm{P}_{j}+\mathrm{C}_{k}+\mathrm{e}_{i j k},
$$

where $\mathrm{Y}_{i j k}=$ observation; $\mu=$ population mean; $\mathrm{E}_{i}=$ $\mathrm{EF}$ effect $(i=1,2) ; \mathrm{F}_{l}=$ forage to concentrate ratio effect $(l=1,2) ; \mathrm{P}_{j}=\operatorname{period}(j=1,2,3$, or 4$) ; \mathrm{C}_{k}=$ random effect of cow $(k=1,2, \ldots$, or 20$) ; \mathrm{C}_{k}=$ $\sim N\left(0, \sigma_{\text {cow }}^{2}\right)$; and $\mathrm{e}_{i j k}=$ residual error, $\mathrm{e}_{i j k} \sim N\left(0, \sigma_{e}^{2}\right)$. Data of ruminal fermentation were analyzed as repeated measurements across time using the MIXED procedure of SAS (SAS Institute, 1989) with the following model:

$$
\mathrm{Y}_{i j k l}=\mu+\mathrm{T}_{i}+\mathrm{P}_{j}+\mathrm{C}_{k}+\mathrm{S}_{l}+\mathrm{T}_{i} \times \mathrm{S}_{l}+\mathrm{e}_{i j k l},
$$

where $\mathrm{Y}_{i j k l}=$ observation; $\mu=$ population mean; $\mathrm{T}_{i}=$ treatment $(i=1,2,3$, or 4$) ; \mathrm{P}_{j}=\operatorname{period}(j=1,2,3$, or 4$) ; \mathrm{C}_{k}=$ random effect of cow $(k=1,2,3$, or 4$), \mathrm{C}_{k}$ $=\sim N\left(0, \sigma_{\text {cow }}^{2}\right) ; \mathrm{S}_{l}=$ sampling time $(l=0,1, \ldots$, or $12 \mathrm{~h}) ; \mathrm{T}_{i} \times \mathrm{S}_{l}=$ treatment $\times$ time interaction; and $\mathrm{e}_{i j k}$ $=$ residual error, $\mathrm{e}_{\mathrm{ijk}} \sim N\left(0, \sigma_{\text {cow }}^{2}\right)$. Significance was declared at $P<0.05$.

\section{RESULTS AND DISCUSSION}

\section{Feed Intake, Milk Yield, and Milk Composition}

The chemical composition of the EF product (OmegaPlus) used in this study is shown in Table 2. The product contained less FA and C18:3 and more CP than traditional EF (Gonthier et al., 2004). This can be attributed to the partial loss of oil and the addition of ground alfalfa meal. Intakes of DM and $\mathrm{CP}$ were not affected by dietary treatment and averaged 26.7 and $4.5 \mathrm{~kg} / \mathrm{d}$, respectively (Table 2 ). However, cows fed the high-forage diets consumed more $(P<0.05)$ NDF than cows fed the low-forage diets, likely due to their higher NDF contents. Dry matter intake for high-producing cows in early lactation can be limited by high dietary NDF due to rumen fill effect (Allen, 2000). For example, diets containing more than $32 \% \mathrm{NDF}$ are expected to limit DMI of high-producing dairy cows (Zebeli et al., 2008). However, all diets in the present study contained less than $32 \%$ NDF. The lack of effect of EF supplementation on DMI agrees with previous studies which showed that inclusion of processed flaxseed in diets of dairy cows in early lactation up to $10 \%$ of the diet DM had no negative effect on DMI (Gonthier et al., 2005; Hurtaud et al., 2010; Petit, 2010).

Milk yield was not influenced by dietary treatment; however, ECM, 4\% FCM, and SCM were all higher $(P$ $<0.05)$ for cows fed the high-forage diets than for those fed the low-forage diets (Table 2). In agreement with our findings, Loor et al. (2005) found no difference in milk yield of cows fed a low- (35:65) or high- (65:35) concentrate to forage diet. The lack of effect of dietary treatments on milk yield is likely due to similar intakes of $\mathrm{DM}$ and $\mathrm{NE}_{\mathrm{L}}$. Milk yield is generally correlated to DMI (NRC, 2001), and in studies where DMI of cows responded positively to low-forage diets, an increase in milk yield has also been observed (Voelker et al., 2002). The lack of response in milk yield as a result of flaxseed supplementation agrees with previous studies (Mustafa et al., 2003; Gonthier et al., 2005). In a review of the literature, Petit (2010) reported no effect of flaxseed supplementation (up to $11 \%$ of diet DM) on milk yield of dairy cows in early lactation.

Milk composition was influenced by the forage to concentrate ratio, but not by EF inclusion (Table 3). Cows fed high-forage diets produced milk with higher $(P<0.05)$ fat and TS concentrations but lower $(P<$ 
0.05) protein and lactose concentrations than cows fed the low-forage diets (Table 3). Our results agree with previous studies, which showed no effect of flaxseed inclusion up to $12 \%$ of the diet DM on milk composition (Martin et al., 2008; Petit et al., 2009). However, few studies showed a reduction in milk fat concentration when unheated (Mustafa et al., 2003) or EF (Moallem, 2009) were fed to dairy cows.

Reducing the forage to concentrate ratio is generally associated with lower milk fat and higher milk protein concentration (Yang and Beauchemin, 2007; Aguerre et al., 2011). A significant decrease in milk fat concentration is usually observed when diets contain $60 \%$ concentrates or higher (Chilliard et al., 2007). The higher NDF to starch ratio in the high-forage than the low-forage diets (1.43 vs. 1.05) may explain the difference in milk fat concentration between dietary treatments. Previous studies reported a positive relationship between NDF to starch ratio and milk fat concentration (Beckman and Weiss, 2005). Slater et al. (2000) indicated that increasing ruminally degradable starch decreases milk fat concentration without affecting milk yield. Feeding low-forage diets is a major cause of diet-induced milk fat depression (Palmquist and Beaulieu, 1993; Bauman and Griinari, 2003). This is mainly due to the fact that low-forage diets modify ruminal biohydrogenation of dietary FA resulting in the accumulation of trans FA, which inhibits FA synthesis in the mammary gland.
The reduction in milk protein and milk lactose concentrations associated with high-forage diets is likely due to a reduction in the supply of gluconeogenic precursors such as propionate and metabolizable protein (Broderick, 2003; Jenkins and McGuire, 2006; Sterk et al., 2011).

\section{Ruminal Fermentation and Total-Tract Digestibility}

No treatment $\times$ time interactions were observed; therefore, only mean effects of dietary treatment were presented (Table 4). Ruminal pH and total VFA concentration were not influenced by dietary treatments (Table 4). In agreement with our findings, Yang et al. (2001) showed no effects of forage to concentrate ratio (35:65 vs. 55:45) on ruminal $\mathrm{pH}$ or total VFA. Molar proportion of acetate was higher $(P<0.05)$; whereas that of propionate was lower $(P<0.05)$ for cows fed the high-forage diets relative to cows fed the low-forage diets. Consequently, acetate to propionate ratio was reduced by feeding cows with high-concentrate diets. Other researchers reported similar effects of forage to concentrate ratio on molar proportions of ruminal acetate and propionate (Yang et al., 2001; Voelker et al., 2002). A recent study by Maxin et al. (2011) suggests that propionate can contribute to milk fat depression when feeding cows with low-forage diets by reducing the concentrations of the main precursor of de novo

Table 3. Effects of extruded flaxseed supplementation and forage to concentrate ratio on performance of dairy cows

\begin{tabular}{|c|c|c|c|c|c|c|c|c|}
\hline \multirow[b]{3}{*}{ Item } & \multicolumn{4}{|c|}{ Treatment } & \multirow[b]{3}{*}{ SEM } & \multirow{2}{*}{\multicolumn{3}{|c|}{$P$-value ${ }^{1}$}} \\
\hline & \multicolumn{2}{|c|}{ 60:40 forage:concentrate } & \multicolumn{2}{|c|}{ 40:60 forage:concentrate } & & & & \\
\hline & No flaxseed & Flaxseed & No flaxseed & Flaxseed & & 1 & 2 & 3 \\
\hline \multicolumn{9}{|l|}{ Intake } \\
\hline DM, kg/d & 26.6 & 27.2 & 26.2 & 26.7 & 0.75 & 0.13 & 0.23 & 0.84 \\
\hline DM, \% BW & 4.1 & 4.2 & 4.1 & 4.1 & 0.16 & 0.15 & 0.29 & 0.75 \\
\hline $\mathrm{CP}, \mathrm{kg} / \mathrm{d}$ & 4.4 & 4.7 & 4.5 & 4.6 & 0.15 & 0.07 & 0.44 & 0.29 \\
\hline NDF, kg/d & 8.1 & 8.6 & 7.7 & 7.8 & 0.29 & 0.01 & $<0.01$ & 0.12 \\
\hline $\mathrm{NDF}, \% \mathrm{BW}$ & 1.2 & 1.3 & 1.2 & 1.2 & 0.06 & 0.01 & $<0.01$ & 0.10 \\
\hline \multicolumn{9}{|l|}{ Yield, $\mathrm{kg} / \mathrm{d}$} \\
\hline Milk & 39.7 & 39.7 & 40.0 & 41.4 & 2.21 & 0.54 & 0.38 & 0.54 \\
\hline ECM & 41.2 & 40.7 & 37.9 & 38.3 & 2.13 & 0.92 & 0.01 & 0.64 \\
\hline $4 \% \mathrm{FCM}$ & 38.7 & 37.9 & 34.2 & 34.4 & 2.10 & 0.75 & $<0.01$ & 0.63 \\
\hline SCM & 38.4 & 38.2 & 35.6 & 35.6 & 1.94 & 0.92 & 0.01 & 0.88 \\
\hline Fat & 1.52 & 1.547 & 1.21 & 1.19 & 0.089 & 0.39 & $<0.01$ & 0.74 \\
\hline Protein & 1.24 & 1.26 & 1.33 & 1.36 & 0.059 & 0.32 & $<0.01$ & 0.76 \\
\hline Lactose & 1.84 & 1.85 & 1.89 & 1.95 & 0.103 & 0.46 & 0.18 & 0.55 \\
\hline $\mathrm{TS}$ & 4.98 & 4.99 & 4.82 & 4.87 & 0.249 & 0.83 & 0.26 & 0.89 \\
\hline SNF & 3.47 & 3.53 & 3.61 & 3.68 & 0.179 & 0.48 & 0.12 & 0.95 \\
\hline \multicolumn{9}{|l|}{ Composition, \% } \\
\hline Fat & 3.82 & 3.70 & 3.04 & 2.89 & 0.135 & 0.09 & $<0.01$ & 0.86 \\
\hline Protein & 3.16 & 3.21 & 3.34 & 3.32 & 0.054 & 0.81 & $<0.01$ & 0.30 \\
\hline Lactose & 4.65 & 4.66 & 4.71 & 4.73 & 0.035 & 0.39 & $<0.01$ & 0.91 \\
\hline TS & 12.57 & 12.60 & 12.10 & 11.81 & 0.175 & 0.27 & $<0.01$ & 0.16 \\
\hline SNF & 8.75 & 8.91 & 9.06 & 8.92 & 0.135 & 0.92 & 0.07 & 0.08 \\
\hline MUN, mg/dL & 13.3 & 13.6 & 14.0 & 13.0 & 0.60 & 0.08 & 0.83 & 0.37 \\
\hline Feed efficiency (milk/ DMI) & 1.5 & 1.4 & 1.3 & 1.3 & 0.07 & 0.27 & $<0.01$ & 0.57 \\
\hline
\end{tabular}

${ }^{1} 1=$ extruded flaxseed; $2=$ forage to concentrate ratio; and $3=$ extruded flaxseed $\times$ forage to concentrate ratio. 
Table 4. Effects of flaxseed supplementation and forage to concentrate ratio on ruminal fermentation

\begin{tabular}{|c|c|c|c|c|c|c|c|c|}
\hline Item & \multicolumn{4}{|c|}{ Treatment } & SEM & & & \\
\hline $\mathrm{pH}$ & 5.82 & 5.87 & 5.73 & 5.80 & 0.06 & 0.36 & 0.27 & 0.92 \\
\hline $\mathrm{NH}_{3}-\mathrm{N}, \mathrm{mg} / \mathrm{dL}$ & 14.67 & 16.67 & 10.35 & 11.11 & 1.13 & 0.31 & 0.02 & 0.61 \\
\hline Total VFA, $\mathrm{m} M$ & 147.6 & 162.6 & 159.0 & 157.2 & 6.45 & 0.36 & 0.67 & 0.28 \\
\hline Propionic acid & 30.1 & 30.4 & 35.2 & 35.3 & 1.36 & 0.90 & 0.03 & 0.93 \\
\hline Butyric acid & 19.3 & 17.8 & 18.5 & 18.6 & 0.81 & 0.47 & 0.98 & 0.39 \\
\hline Acetate:propionate & 1.74 & 1.74 & 1.41 & 1.34 & 0.10 & 0.63 & 0.03 & 0.71 \\
\hline
\end{tabular}

${ }^{1} 1=$ extruded flaxseed; $2=$ forage to concentrate ratio; and $3=$ extruded flaxseed $\times$ forage to concentrate ratio.

milk FA synthesis (i.e., acetate and BHBA). Ruminal $\mathrm{NH}_{3}-\mathrm{N}$ was lower $(P<0.05)$ for cows fed the low-forage diets than for cows fed the high-forage diets (Table 4). High-concentrate diets provide more fermentable carbohydrates for ruminal bacteria, which increases the capture of $\mathrm{NH}_{3}-\mathrm{N}$ for microbial growth and therefore reduces the amount of free $\mathrm{NH}_{3}-\mathrm{N}$ in the rumen.

Total-tract digestibility of DM $(P=0.05)$ and NDF $(P<0.01)$ were higher for high-forage than low-forage diets, but not influenced by EF inclusion (Table 5). However, dietary treatment had no effect on total-tract digestibility of OM and CP. Neutral detergent fiber from low-forage diets is expected to have faster passage rate, a shorter ruminal retention time, and therefore lower total-tract digestibility than NDF from highforage diets (Voelker et al., 2002).

\section{Milk FA Profile}

Milk FA composition was affected by both forage to concentrate ratio and EF supplementation (Table $6)$. Cows fed high-forage diets had higher $(P<0.05)$ concentrations of $\mathrm{C} 4$ to $\mathrm{C} 8 \mathrm{FA}$ but lower $(P<0.05)$ concentrations of $\mathrm{C} 12: 0$ and C14:0 than cows fed lowforage diets. Concentrations of milk FA up to C14 were not influenced by EF supplementation, which is in agreement with Moallem (2009), who reported no effect of feeding EF (4\% of diet DM) on milk short-chain
FA concentrations. However, our results are in contrast with other studies that showed significant reduction in de novo FA synthesis as a result of flaxseed supplementation (Mustafa et al., 2003; Gonthier et al., 2005); in the present study, the level of supplemental flaxseed might not have been large enough to inhibit de novo FA synthesis. It is well documented that the change in the concentration of milk FA is proportional to the inclusion level of flaxseed (Petit and Gagnon, 2009; Petit, 2010). In a meta-analysis of the response of cow milk FA to lipid supplements from various oilseeds, Glasser et al. (2008) reported that oilseeds rich in C18:3, such as flaxseed, have less inhibitory effects on de novo milk FA synthesis than oilseed rich in C18:2. The authors also reported a greater inhibitory effect of oils than oilseeds.

Milk concentration of $\mathrm{C} 16: 0$ was higher $(P<0.05)$ for cows fed the high-forage diets relative to cows fed the low-forage diets, and was decreased $(P<0.05)$ by EF supplementation (Table 6). Our results on the effects of forage to concentrate ratio on milk $\mathrm{C} 16: 0$ concentration are in agreement with Loor et al. (2005). The negative effect of EF supplementation on milk C16:0 concentration is likely due to the inhibitory effects of long-chain FA on de novo synthesized C16:0 (Glasser et al., 2008). A similar effect of EF supplementation on C16:0 concentration has been reported by Gonthier et al. (2005) and Moallem (2009).

Table 5. Effects of extruded flaxseed supplementation and forage to concentrate ratio on total-tract digestibility of lactating cows

\begin{tabular}{|c|c|c|c|c|c|c|c|c|}
\hline \multirow[b]{2}{*}{ Item } & \multicolumn{4}{|c|}{ Treatment } & \multirow[b]{2}{*}{ SEM } & \multicolumn{3}{|c|}{$P$-value ${ }^{1}$} \\
\hline & No flaxseed & Flaxseed & No flaxseed & Flaxseed & & 1 & 2 & 3 \\
\hline \multicolumn{9}{|c|}{ Total-tract digestibility, $\%$} \\
\hline $\mathrm{DM}$ & 62.8 & 63.2 & 62.0 & 61.1 & 1.56 & 0.72 & 0.05 & 0.39 \\
\hline $\mathrm{OM}$ & 63.8 & 64.7 & 63.6 & 62.6 & 1.52 & 0.95 & 0.16 & 0.25 \\
\hline
\end{tabular}

${ }^{1} 1=$ extruded flaxseed; $2=$ forage to concentrate ratio; and $3=$ extruded flaxseed $\times$ forage to concentrate ratio. 
Table 6. Effects of extruded flaxseed supplementation and forage to concentrate ratio on milk FA profile of lactating cows

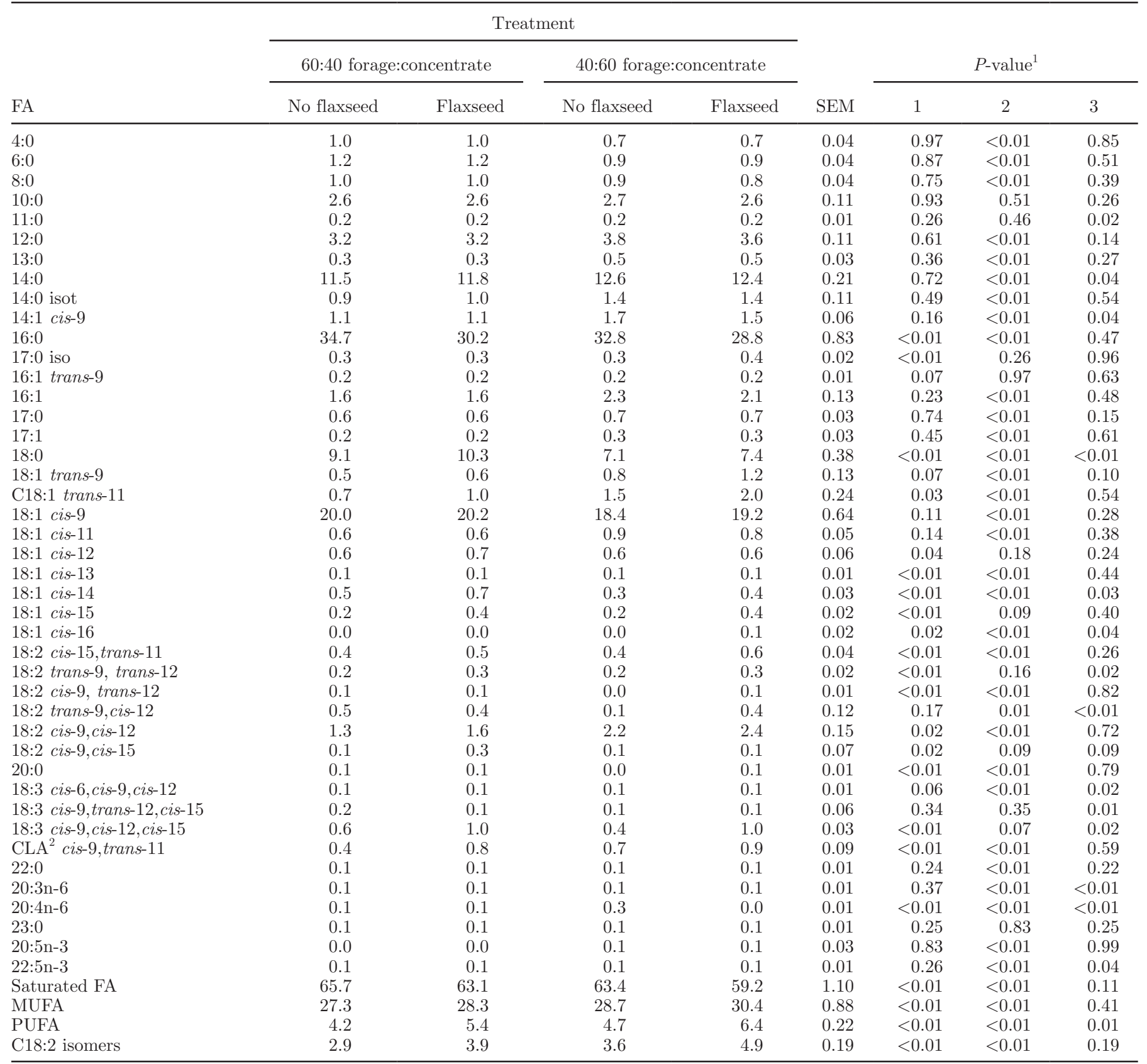

${ }^{1} 1=$ Extruded flaxseed, $2=$ Forage:concentrate ratio, $3=$ Extruded flaxseed $\mathrm{x}$ forage:concentrate ratio.

${ }^{2} \mathrm{CLA}=$ conjugated linoleic acid.

Extruded flaxseed supplementation and high-forage diets increased $(P<0.05)$ the concentration of $\mathrm{C} 18: 0$ milk FA (Table 6). However, the increase was more significant when dairy cows were fed EF together with high-forage than with low-forage diets, as indicated by the forage to concentrate ratio and $\mathrm{EF}$ interaction. The increase in the concentrations of $\mathrm{C} 18 \mathrm{FA}$ with $\mathrm{EF}$ supplementation is likely due to an increase in mammary uptake of C18 FA absorbed in the small intestine (Gonthier et al., 2004).
In the present study, feeding high-concentrate diets reduced C18:0 and milk fat concentrations. Several researchers have reported a high correlation between C18:0 and milk fat content (Chilliard et al., 2003; Loor et al., 2005). Concentration of cis-9 C18:1 was higher $(P<0.05)$ in the milk of cows fed the high-forage diets than cows fed the low-forage diets. However, milk cis-9 C18:1 level was not influenced by EF supplementation. According to Loor and Herbein (2003), the deficiency in endogenously synthesized C18:1 is responsible for re- 
duced milk fat yield as frequently observed with feeding cows high concentrate diets.

Concentrations of $\mathrm{C} 18: 3$ and conjugated linoleic acid (CLA) increased by 100 and 54\%, respectively, as a result of EF supplementation. Feeding high-forage diets increased $(P<0.05)$ the concentration of CLA, but not that of $\mathrm{C} 18: 3$. Forage to concentrate ratio $\times$ EF supplementation interaction $(P<0.05)$ suggested an increase in $\mathrm{C} 18: 3$ concentration when EF was fed with high-concentrate and not low-concentrate diets. Interactions between forage to concentrate ratio and dietary fat on milk FA composition have been reported by other authors. Effects of flaxseed supplementation were higher on $\mathrm{C} 18: 3$ when added to high-concentrate diets and were higher on C18:0 when added to highforage diets (Chilliard and Ferlay, 2004; Dewhurst et al., 2006). Despite significant increases in the concentrations of health-promoting FA such as C18:3 and CLA as a result of extruded flaxseed supplementation, the absolute levels of these FA remained $\leq 1.0 \%$ of total milk FA. These results suggest extensive ruminal biohydrogenation of dietary C18:3 despite the fact that flaxseed was extruded at temperatures approaching $122^{\circ} \mathrm{C}$. Gonthier et al. (2005) also reported low transfer efficiency (i.e., $2 \%$ ) of dietary C18:3 to milk as a result of EF supplementation. Similar low transfer efficiency has also been reported by Chilliard et al. (2001). Gonthier et al. (2005) reported lower milk concentration of C18:3 for cows fed EF relative to those fed micronized flaxseed; this was attributed to the fact that extrusion increased ruminal biohydrogenation of $\mathrm{C} 18: 3$ and reduced the amount of C18:3 reaching the duodenum (Gonthier et al., 2004).

\section{Relationship Between Ruminal Fermentation, Milk FA, and Milk Fat Depression}

It is well documented that diets causing milk fat depression alter ruminal biohydrogenation, causing an increased production of trans FA isomers that inhibits de novo milk fat synthesis (Shingfield et al., 2010). Trans FA, such as trans-10 C18:1 and trans-10, cis-12 CLA, decrease de novo milk fat synthesis by inhibiting key enzymes and proteins in mammary lipid synthesis (Harvatine and Bauman, 2006; Gervais et al., 2009; Shingfield et al., 2010). However, recent studies have shown that the increase in trans FA isomers is insufficient to fully explain the reduction in de novo milk fat synthesis associated with diet-induced milk fat depression (Sutton et al., 2003). On the other hand, high-concentrate diets increase ruminal propionate production, which reduces milk fat concentration and yield (Rulquin et al., 2007; Maxin et al., 2011). Yet, the mechanism by which propionate decreases de novo milk fat synthesis is still unknown. A decrease in the supply of de novo milk FA precursors (i.e., acetate and butyrate) as a result of increased propionate production may be a possible explanation (Maxin et al., 2011).

\section{CONCLUSIONS}

Results of this study showed that most of the effects observed for dairy cow performance, ruminal fermentation and total-tract digestibility were related to the forage to concentrate ratio and not due to EF supplementation. Feed intake and milk yield were not influenced by the forage to concentrate ratio. However, feeding cows high-forage diets increased milk fat and TS concentrations but reduced protein and lactose levels in milk. The reduction in milk fat concentration as a result of feeding high-concentrate diets is likely due to alteration of ruminal fermentation, which resulted in higher levels of FA isomers, such as trans-10 C18:1. Extruded flaxseed supplementation beneficially altered milk FA composition, as indicated by higher concentrations of health-promoting CLA and C18:3, but significantly lowered levels of C16:0 SFA. However, the lack of a major effect of EF on milk FA may be associated with the low inclusion rate and extensive ruminal biohydrogenation.

\section{ACKNOWLEDGMENTS}

Carolane Neveu is a recipient of an Industrial Innovation Scholarship from Fonds Quebecois de la Recherche sur la Nature et les Technologies, Natural Sciences and Engineering Research Council of Canada, and Bélisle Solution Nutrition Inc. The authors thank N. Gentesse (Bélisle Solution and Nutrition Inc., Saint-Mathias sur Richelieu, Canada) for diet formulation.

\section{REFERENCES}

Aguerre, M. J., M. A. Wattiaux, J. M. Powell, G. A. Broderick, and C. Arndt. 2011. Effect of forage-to-concentrate ratio in dairy cow diets on emission of methane, carbon dioxide, and ammonia, lactation performance, and manure excretion. J. Dairy Sci. 94:3081-3093.

Akraim, F., M. C. Nicot, P. Juaneda, and F. Enjalbert. 2007. Conjugated linolenic acid (CLnA), conjugated linoleic acid (CLA) and other biohydrogenation intermediates in plasma and milk fat cows fed raw or extruded linseed. Animal 1:835-843.

Allen, M. S. 2000. Effects of diet on short-term regulation of feed intake by lactating dairy cattle. J. Dairy Sci. 83:1598-1624.

Andersson, R., and B. Hedlund. 1983. HPLC analysis of organic acids in lactic acid fermented vegetables. Z. Lebensm. Unters. Forsch. 176:440-443.

AOAC. 1990. Official Methods of Analysis. 15th ed. Vol 1. Assoc. Off. Anal. Chem., Arlington, VA.

Beckman, J. L., and W. P. Weiss. 2005. Nutrient digestibility of diets with different fiber to starch ratios when fed to lactating dairy cows. J. Dairy Sci. 88:1015-1023.

Broderick, G. A. 2003. Effects of varying dietary protein and energy levels on the production of lactating dairy cows. J. Dairy Sci. $86: 1370-1381$. 
Chilliard, Y., and A. Ferlay. 2004. Dietary lipids and forage interactions on cow and goat milk fatty acid composition and sensory properties. Reprod. Nutr. Dev. 44:467-492.

Chilliard, Y., A. Ferlay, and M. Doreau. 2001. Effect of different types of forages, animal fat or marine oils in cow's diet on milk fat secretion and composition, especially conjugated linoleic acid (CLA) and polyunsaturated fatty acids. Livest. Prod. Sci. 70:31-48.

Chilliard, Y., A. Ferlay, J. Rouel, and G. Lamberett. 2003. A review of nutritional and physiological factors affecting goat milk lipid synthesis and lipolysis. J. Dairy Sci. 86:1751-1770.

Chilliard, Y., F. Glasser, A. Ferlay, L. Bernard, J. Rouel, and M. Doreau. 2007. Diet, rumen biohydrogenation and nutritional quality of cow and goat milk fat. Eur. J. Lipid Sci. Technol. 109:828-855.

Chouinard, P. Y., J. Lévesque, V. Girard, and G. J. Brisson. 1997. Dietary soybeans extruded at different temperatures: Milk composition and in situ fatty acid reactions. J. Dairy Sci. 80:2913-2924.

Dewhurst, R. J., K. J. Shingfield, M. R. F. Lee, and N. D. Scolan. 2006. Increasing the concentrations of beneficial polyunsaturated fatty acids in milk produced by dairy cows in high-forage systems. Anim. Feed Sci. Technol. 131:168-206.

Gervais, R., J. W. McFadden, A. J. Lengi, B. A. Corl, and P. Y. Chouinard. 2009. Effects of intravenous infusion of trans-10,cis-12 18:2 on mammary lipid metabolism in lactating dairy cows. J. Dairy Sci. 92:5167-5177.

Glasser, F., A. Ferlay, and Y. Chilliard. 2008. Oilseed lipid supplements and fatty acid composition of cow milk: A meta-analysis. J. Dairy Sci. 91:4687-4703.

Gonthier, C., A. F. Mustafa, R. Berthiaume, H. V. Petit, R. Martineau, and D. R. Ouellet. 2004. Effects of feeding micronized and extruded flaxseed on ruminal fermentation and nutrient utilization by dairy cows. J. Dairy Sci. 87:1854-1863.

Gonthier, C., A. F. Mustafa, D. R. Ouellet, P. Y. Chouinard, R. Berthiaume, and H. V. Petit. 2005. Feeding micronized and extruded flaxseed to dairy cows: Effects on blood parameters and milk fatty acid composition. J. Dairy Sci. 88:748-756.

Harvatine, K. J., and D. E. Bauman. 2006. SREBP1 and thyroid hormone responsive spot 14 (S14) are involved in the regulation of bovine mammary lipid synthesis during diet-induced milk fat depression and treatment with CLA. J. Nutr. 136:2468-2474.

Huhtanen, P., K. Kaustell, and S. Jaakkola. 1994. The use of internal markers to predict total digestibility and duodenal flow of nutrients in cattle given six different diets. Anim. Feed Sci. Technol. $48: 211-227$.

Hurtaud, C., F. Faucon, S. Couvreur, and J.-L. Peyraud. 2010. Linear relationship between increasing amounts of extruded linseed in dairy cow diet and milk fatty acid composition and butter properties. J. Dairy Sci. 93:1429-1443.

Jenkins, T. C., and M. A. McGuire. 2006. Major advances in nutrition: Impact on milk composition. J. Dairy Sci. 89:1302-1310.

Kelzer, J. M., P. Kononoff, A. M. Gehman, L. O. Tedeschi, K. Karges, and M. L. Gibson. 2009. Effects of feeding three types of cornmilling coproducts on milk production and ruminal fermentation of lactating Holstein cattle. J. Dairy Sci. 92:5120-5132.

Kennelly, J. J. 1996. The fatty acid composition of milk fat as influenced by feeding oilseeds. Anim. Feed Sci. Technol. 60:137-152.

Loor, J. J., A. Ferlay, A. Ollier, M. Doreau, and Y. Chilliard. 2005. Relationship among trans and conjugated fatty acids and bovine milk fat yield due to dietary concentrate and linseed oil. J. Dairy Sci. 88:726-740.

Loor, J. J., and J. H. Herbein. 2003. Reduced fatty acid synthesis and desaturation due to exogenous trans10, cis12-CLA in cows fed oleic or linoleic oil. J. Dairy Sci. 86:1354-1369.

Martin, C., J. Rouel, J. P. Jouany, M. Doreau, and Y. Chilliard. 2008. Methane output and diet digestibility in response to feeding dairy cows crude linseed, extruded linseed, or linseed oil. J. Anim. Sci. $86: 2642-2650$

Maxin, G., F. Glasser, C. Hurtaud, J. L. Peyraud, and H. Rulquin. 2011. Combined effects of trans-10,cis-12 conjugated linoleic acid, propionate, and acetate on milk fat yield and composition in dairy cows. J. Dairy Sci. 94:2051-2059.
Moallem, U. 2009. The effects of extruded flaxseed supplementation to high yielding dairy cows on milk production and milk fatty acid composition. Anim. Feed Sci. Technol. 152:232-242.

Mustafa, A. F., P. Y. Chouinard, and D. A. Christensen. 2003. Effects of feeding micronized flaxseed on yield and composition of milk from Holstein cows. J. Sci. Food Agric. 83:920-926.

National Research Council. 2001. Nutrient Requirements of Dairy Cattle. 7th rev. ed. National Academy Press, Washington, DC.

O'Fallon, J. V., J. R. Busboom, M. L. Nelson, and C. T. Gaskins 2007. A direct method for fatty acid methyl ester (FAME) synthesis: Application to wet meat tissues, oils and feedstuffs. J. Anim. Sci. 85:1511-1521

Palmquist, D. L., and A. D. Beaulieu. 1993. Feed and animal factors influencing milk fat composition. J. Dairy Sci. 76:1753-1771.

Petit, H. V. 2010. Review: Feed intake, milk production and milk composition of dairy cows fed flaxseed. Can. J. Anim. Sci. 90:115-127.

Petit, H. V., and N. Gagnon. 2009. Milk concentrations of the mammalian lignans enterolactone and enterodiol, milk production, and whole tract digestibility of dairy cows fed diets containing different concentrations of flaxseed meal. Anim. Feed Sci. Technol. 152:103-111.

Petit, H. V., N. Gagnon, P. Mir, R. Cao, and S. Cui. 2009. Milk concentration of the mammalian lignan enterolactone, milk production, milk fatty acid profile, and digestibility of dairy cows fed diets containing whole flaxseed or flaxseed meal. J. Dairy Res. $76: 257-264$

Rulquin, H. C.. S. Hurtaud, S. Lemosqut, and J. L. Peyraud. 2007. Quantification of the effects of energetic nutrients on fat content of cow milk. INRA Prod. Anim. 20:163-173.

SAS Institute. 1989. SAS User's Guide: Statistics. SAS Institute Inc., Cary, NC.

Shingfield, K. J., L. Bernard, C. Leroux, and Y. Chilliard. 2010. Role of trans fatty acids in the nutritional regulation of mammary lipogenesis in ruminants. Animal 4:1140-1166.

Slater, A. L., M. L. Eastridge, J. L. Firkins, and L. J. Bidinger. 2000. Effects of starch source and level of forage neutral detergent fiber on performance of dairy cows. J. Dairy Sci. 83:313-321.

Sterk, A., B. E. O. Johansson, H. Z. H. Taweel, M. Murphy, A. M. Van Vuuren, W. H. Hendriks, and J. Dijkstra. 2011. Effects of forage type, forage to concentrate ratio, and crushed linseed supplementation on milk fatty acid profile in lactating dairy cows. J. Dairy Sci. 94:6078-6091

Sutton, J. D., M. S. Dhanoa, S. V. Morant, J. France, D. J. Napper, and E. Schuller. 2003. Rates of production of acetate, propionate, and butyrate in the rumen of lactating dairy cows given normal and low-roughage diets. J. Dairy Sci. 86:3620-3633.

Van Soest, P. J., P. J. Robertson, and B. A. Lewis. 1991. Methods for dietary fiber, neutral detergent fiber, and nonstarch polysaccharides in relation to animal nutrition. J. Dairy Sci. 74:3583-3597.

Voelker, J. A., G. M. Burato, and M. S. Allen. 2002. Effects of pretria milk yield on responses of feed intake, digestion, and production to dietary forage concentration. J. Dairy Sci. 85:2650-2661.

Weiss, W. P., H. R. Conrad, and N. R. St. Pierre. 1992. A theoretically based model for predicting total digestible nutrient values of forages and concentrates. Anim. Feed Sci. Technol. 39:95-110.

Yang, W. Z., and K. A. Beauchemin. 2007. Altering physically effective fiber intake through forage proportion and particle length: Chewing and ruminal pH. J. Dairy Sci. 90:2826-2838.

Yang, W. Z., K. A. Beauchemin, and L. M. Rode. 2001. Effects of grain processing, forage to concentrate ratio, and forage particle size on rumen $\mathrm{pH}$ and digestion by dairy cows. J. Dairy Sci 84:2203-2216

Zebeli, Q., J. Dijkstra, M. Tafaj, H. Steigass, B. N. Ametaj, and W Drochner. 2008. Modeling the adequacy of dietary fiber in dairy cows based on the response of ruminal $\mathrm{pH}$ and milk fat production to composition of the diet. J. Dairy Sci. 91:2046-2066. 